\title{
Omnibus Law in the Perspective of Constitutionality and Legal Policy
}

\author{
Abdul Hakim Siagian1 \\ ${ }^{1}$ Faculty of Law, Universitas Muhammadiyah Sumatera Utara, Indonesia. Email: \\ abdulhakim@umsu.ac.id
}

\section{Article Info}

\section{Keywords:}

Omnibus Law;

Constitutionality;

Certainty.

How to cite $(A P A$

Citation Style):

Siagian, Abdul

Hakim. (2021).

Omnibus Law in the

Perspective of

Constitutionality and

Legal Policy”.

Jambura Law

Review. JALREV 3

(1): 93-111

\begin{abstract}
Overlapping norms in regulations, for example in the Natural Resources sector in terms of ease of investment, which previously had been sufficiently well regulated in the Law, many of the rules were cut through the omnibus law. The issues to be discussed are the constitutionality of the omnibus law concept in achieving legal certainty and usefulness in Indonesia. The research method used is normative juridical legal research. The results show that the omnibus law will also not interfere with the hierarchy of statutory regulations because the omnibus law is actually applied the same as the usual statutory regulation formation system. Apart from that, the omnibus law will also provide significant legal objectives in the form of legal certainty and usefulness compared to the normal law revision method (one by one).
\end{abstract}




\section{Introduction}

Indonesia is a democratic legal state. This gives the implication of the presence of all the joints of life with the laws and regulations of a democratic. On the one hand, the principle is producing many rules are very complex, at present Indonesia has at least about 42 thousand regulations which tend to overlap, both in hierarchy regulations of the center and in the regions sometimes cause the value of legal certainty (legal certainly) and legal benefits are often not achieved. And also led to government decision-making is slow. ${ }^{1}$

There are several examples of the shape of the overlap of the norms in the regulations, such as in the Natural Resources sector in terms of the ease of investing, where there are Laws that contradiction, namely Law Number 41 of 1999 on Forestry, Law Number 32 of 2009 about Protection and Management of the Environment and the Law Number 5 of 1960 about Basic Agrarian. In terms of anti-corruption, Law Number 30 of 2014 on Government Administration and Law No. 31 of 1999 on Corruption has contradictions of normative and philosophical related recognition in the explicit element of evil intent or mens rea. In terms of agency business law, Law Number 40 of 2007 about Limited liability Company and Law No. 20 of 2008 on SMES experiencing disharmony in terms of the determination of the initial capital of the business. Then, the Law of PT in relation to PT, state-owned enterprises in terms of management of the wealth of the country is experiencing disharmony with the Law Number 17 of 2003 on State property, which resulted in the board of directors of PT, the state can be entangled Article 1, Paragraph 2 of the Law of Criminal Embezzler.

This gives the impact of not achieving the goal of legal certainty and expediency of the law because of the overlap and norms which contradict each other. In addition, this will provide a negative impact on economic growth where over-regulation will complicate investors in providing capital investment in Indonesia. This will give the impact for the weak economic growth in Indonesia, because in addition to the norms overlap and conflict, also caused by the length of the chain of bureaucracy to start trying in the economic sector in Indonesia.

\section{Problem Statement}

1 Agnes Fitryantica. (2019). Harmonisasi Peraturan Perundang-undangan Indonesia Melalui Konsep Omnibus Law. Jurnal Gema Keadilan. 6 (3): 301. 
In addressing the issue of hyper-regulation and overlapping regulation, deregulation through the concept of the omnibus law is the ideal path. Although there are many theses against the concept of the omnibus law, it should be in the study of constitutional law see a problem with basing on the concept-the concept of the state. Therefore it is necessary to analyze how the factors of political, economic, social, cultural in the formation of political law the concept of the omnibus law and how the constitutionality of the approach of the omnibus law in the context of the science of comparative law, in particular, the method of legal transplants are used in the application of the omnibus law in Indonesia. This case can be seen through the concept of political law and the concept of comparative law that specifically use the method of transplantation of law. It is used to see the goal of the state which is set in the official policies of the state and social purpose in the constitution through the omnibus law. In addition, it will also give you a view of the constitutionality of the concept of the omnibus law in achieving certainty and utility of the law in Indonesia.

\section{Method}

This research using methods qualitative with the type of descriptive analysis where the process of data collection is done by literature study (library research) from various literature such as journals, media, textbooks, and research publications. Library research using written documents as data and data sources include primary legal materials, secondary legal materials, and tertiary legal materials. Primary legal materials are the material law that is valid in the study of binding and the observance of the law. Secondary legal materials is a description of the primary legal materials in the form of doctrines found in books, journals, and scientific publications.

\section{Discussion}

\subsection{Political Law Configuration of the Formation of the Omnibus Law Legislation in Indonesia}

Understanding the concept of Omnibus Law can be started with literal understanding. Etymologically, Omnibus comes from Latin, which means everything. Bryan a called the omnibus as, relating to various objects or objects at once; including many things or having various purposes (related to or satisfied with Bernan Bernan as an item at once; 
Crazy to be coupled with the law of words, then the meaning is wrong for all. In the common law tradition, efforts to reform legislation to change, and others to make any character changes, but based on different facts.

Even though there is a lot of debate and rejection of the omnibus law concept that will be implemented in Indonesia at this time, this can be understood as a mistake in thinking. This is because the rejection of the conceptualization of the omnibus law is not based on a conceptual approach to the omnibus law a sich, but through an issue approach that tends to the legal substance contained in statutory regulations. These are clearly two different things. ${ }^{2}$

However, in a process of making laws and regulations, it is inseparable from different views. However, in the context of constitutional law, the assessment analysis is usually based on the concept of political law. As a comprehensive and holistic perspective in looking at a legal product that will be assessed. According to Moh. Mahfud MD, political law includes at least three things, namely: first, the official state policy (official line) regarding the law that will be enforced or not enforced in order to achieve the country's goals, second, political, economic, social, cultural background on the birth of legal products, third, law enforcement in reality in the field.

Based on this concept, at least in this case using the first two concepts in the analysis. First, in terms of official state policies in order to achieve state goals, the constitution mandates a state goal that must be achieved, one of which is advancing public welfare. More concretely, the body of the constitution mandates Article 27 paragraph 2 of the 1945 Constitution which stipulates that every citizen has the right to work and a living that is decent for humanity. Therefore, the state needs to make efforts to fulfill the rights of citizens to obtain decent work and livelihoods.

Indonesia as a rule of law adheres to the concept of a welfare state which avoids the principle of "laissez faire, laissez aller", in economic affairs which prohibits the state and government from interfering in the economic life of its people. (staatsbemoeienis). In short, the state should intervene as little as possible in people's lives and businesses. The failure of the nachwachtersstaat concept which limits the state and government as a 
result torments the people and causes social unrest. The implication is to create a welfare state by transferring the staatsonthouding principle to biotechnology which obliges the state to realize general welfare for its people.

With this concept, Presthus stated that the state has two tasks, namely: (i) policy making, determining the state's direction, (ii) task executing, namely the implementation of tasks according to the direction set by the state. Therefore, the state has an obligation to determine the direction of the state, in the form of efforts to achieve general welfare goals by improving and improving the domestic investment climate and implementing regulatory simplification strategies as an effort to encourage state policy through the application of the omnibus law concept in the context of regulations in the economic sector in Indonesia.

Second, the background of the socio-cultural-economic politics that encourages the use of the omnibus law concept can be seen in several factors, namely economic factors. In the Indonesian National Medium-Term Development Plan, there are problems faced in increasing investment, namely a bad investment climate due to various factors, which can be divided into two factors, namely (i) internal investment factors, in the form of long and expensive investment licensing procedures, weak incentives investment, and the absence of clear policies to encourage technology transfer from foreign investment, (ii) external factors of investment in the form of low legal certainty and low quality of human resources and limited infrastructure. ${ }^{3}$ In addition, there are 10 World Bank indicators to measure ease of doing business, of which 6 indicators are considered poor in Indonesia, namely: indicators of ease of starting a business, construction permits, building registration, paying taxes, compliance with contracts, and cross-border trade. ${ }^{4}$

Apart from that, in Indonesia's 2045 vision, Indonesia has a goal to become the 5 (five) major world economic powers. Which through the National Development Planning Agency's RPJMN document for 2020-2024, targets the growth of per capita Gross Domestic Product (PBD) of 4 percent, which will exclude Indonesia from the Middle Income Trap (MIT) in 2036. Economic growth is slowing down to around 5 percent, Indonesia is still an Upper Middle-Income country in 2019 with a Gross National Income

3 Vincent Suriadinata. (2019). Penyusunan Undang-Undang di Bidang Investasi: Kajian Pembentukan Omnibus Law di Indonesia. Jurnal Ilmu Hukum Refleksi Hukum. 4 (1). p. 122.

4 Henry Donal, Ibid., p. 464 
(GNI) per capita of USD 6,010. With a GDP per capita of Rp. 56 million per year, the nominal GDP value of Rp. 14,873.4 T and a poverty rate of 9.66 percent and economic growth in the last decade of 5.4 percent, it took 13 years to reach PBD per capita to Rp. 78.8 million per year. And to achieve Indonesia's target in 2045 with a per capita income of Rp. 320 million per year has not been achieved in 39 years, even though the remaining time is now only 25 years. $^{5}$

Therefore, there are at least 3 aspects that become the focus of economic improvement, namely the issue of low competitiveness, slowing economic growth, and uneven economic growth. These three problems are caused, among others, by Indonesia's unfavorable business climate and low and uneven investment. Basically, this whole thing is the result of complicated problems or difficulties in doing business in Indonesia due to so many regulations (over-regulated) in the licensing sector whose substance is not harmonious, overlaps, and even contradicts one another from the central and regional governments, and the long bureaucratic chain. ${ }^{6}$

Such factors have previously been trying to attempt to be solved by the government, for example through a policy of One Door Integrated Service (PTSP) and also through the trimming of regulation in the Economic Policy Package (PKE) as outlined in Presidential Regulation Number 91 of 2017 about the Acceleration of the Implementation of Trying. Furthermore, to keep the commitment, the government also issued Government Regulation No. 24 of 2018 about Licensing Services Seeks Integrated Electronically or known as the Online Single Submission (OSS), which cut the 537 permits to be 237 permits and 362 non-permission to 215 non-permission. But at the level of the norm is still impaired hierarchy with the norms of licensing which is regulated in the Legislation. Where regulations are hierarchy below must not conflict with the rules above in accordance with Article 7, paragraph 1 of LAW Number 12 of 2011, in this case, Government Regulation and Presidential Regulation must not conflict with the Legislation.

Indonesia is blessed, a wealth of natural biodiversity, water, climate, and soil conditions that provide a source of life to the nation, especially in the field of agriculture so that not

Naskah Akademis RUU Ciptakerja, 2020, h. 1-4

6 Ibid.

https://ejurnal.ung.ac.id/index.php/jalrev/index

JALREV3(1)2021 
surprising, this country used to be known as the "Emerald of the Equator" to ignite many countries to master it. History records that be one of the factors the arrival of Europeans to Indonesia to the desire to colonize "the earth is the equator" are the potential of Indonesia's natural resources are abundant and the availability of an assortment of herbs that can't be found in other countries.

The agricultural sector is the main pillar that plays an important role in the national economy to absorb labor, the sources of economic growth, and foreign exchange earner. The importance of the development of the real economy in the era of industry 4.0 is seen from without the real economy that awakened, the industry-based technology will eventually die. For example, a delivery service online food will not be running if no one is producing food ingredients. Then the real economy such as agriculture and the industry remains so important part. In addition, the agricultural sector also drives other sectors in the national economy. But unfortunately, a number of complicated problems in the agricultural sector never ends.

First, the degradation of the wetland. The Central Statistics Agency (BPS) 2019 show a lot of extensive rice fields are missing. In the report Indicator of the Welfare of the People of 2019 BPS states, in 2012, the wetland reaches 8.127.264 acres, continued to decline until 8.087.393 acres. This phenomenon is allegedly due to rising demand for residential and the dispute of land for plantation or construction of public facilities. It is proved over the function of the land is still a serious problem because it involves food security. Therefore, each year land in Indonesia has occurred shrinkage to reach 100 thousand hectares. Whereas one side of our population more and more, on the other hand, there is shrinkage of land area raw. Mastery of the land by mafia-land mafia also worsens the situation of Indonesian farmers. The development of hydroponics indeed provides advantages in the degradation of this land. Although predicted as a solution to overcome the limitations of land, but a hydroponic system also has shortcomings such as Investment at the beginning of quite expensive especially on a large scale. The capital to buy tools and materials required. Then the equipment and maintenance are still rare. A hydroponic system has not been so popular in the community in Indonesia so that special tools will be difficult to obtain freedom. Similarly, the equipment for maintenance/repair. In addition, it requires accuracy is to actually supervise the nutrition given to the level of acidity of the $\mathrm{pH}$ of the plant. Capital and skills that are not owned by the farmers so that 
the food problem still continues to arise.

Second, the problem of land in agriculture, it raises another dilemma. Complaints related to agrarian conflict enters in the ranking of the five highest related to land cases. The case of agrarian has recorded a presentation of $14 \%$ of the total community complaints. The settlement of the conflict should be the main priority of the agrarian reform program. Non-governmental organizations, the Consortium for Agrarian reform, noting happens 1.771 cases of agrarian conflict in the era of Jokowi's government in 2015-2018. The consortium noted a conflict in the era of Jokowi, which killed 41 people, including activists of human rights. Agrarian reform initiated by President Joko Widodo should be implemented to resolve land conflicts in the community. The agrarian conflict will remain fertile if the government's policy on land don't parse the root of the problem is there. The agrarian conflict will remain fertile if the government's policy on land don't parse the root of the problem is there. Government policies that do not involve the community in granting, to the state-owned enterprises, government projects, and private companies, become the main cause of agrarian conflict. Often times the government issued the lease rights or mining permit, whereas on the land there are villages and communities that work the land. Although certification of the land is still needed to avoid land disputes, the program should not be the main agenda of agrarian reform. Distribution of certificates for this is done to clear the landowner. If the purpose of the certification is to resolve the agrarian conflict, a certificate should be given to the community where the land is located in the maelstrom of conflict.

Third, the welfare of farmers far from the fire. The welfare of farmers should be a priority for the sake of ensuring that one of the wheels of the cantilever of the national economy continues to move and contribute. Data compiled by BPS (2018) noted that the nominal wage of agricultural laborers at the beginning of the year 2009 amounting to Rp36.190 and continue to experience an increase to Rp51.598 in March 2018. However, real wages recorded in the value of Rp30.551 (2009) and a not too significant increase, Rp30.602 (2018). Based on BPS data, the average nominal wage of agricultural laborers in January 2019 amounted to Rp53.604 per day. Thus, in one month, the wages of farmers using the count of the ranges R1,68 million per month. While the UMP (Provincial Minimum Wage) 2019 low set IN Yogyakarta amounting to Rp1,57 million per month. This fact explains though the value of the nominal daily wage of farmers is likely to increase when 
compared against the price of the goods there are (real) is relatively constant. There is a gap relatively large between the two wages.

Fourth, the decline in the exchange rate of farmers. BPS recorded a decline in the Exchange rate of Farmers (NTP) worth 0.21 percent in March 2019 for month-to-month (mom). In general, the NTP combined for various sectors worth 102,73 . NTP is a comparison of prices received by farmers and an index of prices paid by farmers. In general, the NTP be an indicator of purchasing power due to be able to see how capable a farmer exchanging the product of his farm into the goods and services consumed or used back in the cost of production. The changes most keenly are the NTP plant food that fell 1.33 percent from the previous month. This should be a concern of the government. Farmers are in a difficult position because of the selling price set by the trader. As a manufacturer, the farmer can not set the market price in the middle of the practices of monopoly and oligopoly at this time.

Pancasila and the Constitution must and shall be the source to fill and or change the law of agriculture which is still empty or obsolete, necessarily preceded from the study of holistic about the farm that later became the rule of law as the pattern of substantive law, with the first decide the strategy of the model system the law is the codification total or partial. When the Omnibus law becomes the choice should be the law of agriculture to be the main priority. That's an important part of the strategy of the politics of food to protect, ensure and provide justice for the farmers, not the omnibus the other fields.

That the law of agriculture of Indonesia has not shown a good system, the codification of agreed upon, so a lot of empty space and the norm are obsoletely exacerbated by the commitment to upholding the law of the farm was in good faith so that farmers become victims and even can be said the problem of our agriculture is already complex and that means a serious threat. So referring to the uproarious cry of the omnibus law for and on behalf of the investment then should that be "homework" the government is putting form omnibus law in the agricultural sector in order to protect, provide certainty and fairness in our farmers, not vice versa. Indonesia as an agricultural country should give serious attention to agriculture and to the parties involved should play an active role, of good led by the President for strategic steps.

The reality of Indonesia as an agricultural Country needed law enforcement firmly to 
answer the role of the state and against the practice of monopoly, oligopoly, and cartels that colonize the farmers, need to be established other regulations to fulfill the legal vacuum that occurs. In this case, the idea of an omnibus law on agriculture is an important public interest. So when the choice of the codification of the omnibus law, then agriculture should be a priority and not the other.

\subsection{Measuring the Constitutionality of Omnibus Law Transplantation}

In the theory of legislation, Maria Farida Indrati said, "changes to a statutory regulation are made if there are provisions in the regulation that is no longer in accordance with the conditions of the community". Changes in laws and regulations may include the following: (i) adding or inserting new provisions as well as improving or removing existing provisions, (ii) replacing a provision with other provisions. ${ }^{7}$ By looking at the facts on legal politics above, making the omnibus law an effort to find a way out of the deadlock in a very complex statutory system.

Before entering into the concept of comparative law, it is necessary to look at the omnibus law in practice in other countries. The application of the omnibus law in the Philippines is contained in the omnibus investment code of 1987. The Philippines, which adheres to the common law system, in this case, adheres to a codification that is usually adopted by countries with a civil law system. This is due to the history of the Philippines, which was once colonized by Spain which was then colonized by America, which at that time the codification was still maintained. This illustrates that the characteristics of the omnibus law in the Philippines are codification. The general purpose of the codification itself is to make the collection of laws and regulations simple and easy to master, logically arranged, harmonious, and certain. ${ }^{8}$

The application of the omnibus law in America can be seen through the document The Omnibus Public Land Management Act of 2009 as a regulation of a national landscape conservation system on millions of hectares of protected areas in America. According to Krutz, there is an approach that explains the emergence of the omnibus law which has an impact on institutional changes, namely the individual's will to build a coalition at Congress. What is important to note here is the legislative process in order to succeed in 
becoming law by ensuring a coalition in Congress and avoiding a veto from the President. Where the omnibus law in America helps members of parliament to form a consensus. ${ }^{9}$

In the context of Indonesia, the ideals of statutory regulations should provide the essence of legal certainty for the community, but instead often provide uncertainty caused by the large overlap between hierarchical regulations. So the concept of omnibus law, which is actually a concept in the common law tradition, needs to be transplanted in Indonesia in order to answer the problem of hyper regulating in Indonesia. In the constitutional law discourse related to legal comparisons, Judge Breyer in the Printz v. the United States gave a dissenting opinion stating that there is no completely different solution in solving legal problems, each country can take a general pattern (big pattern) in each context of the problem. This illustrates the importance of a country adopting or transplanting a legal structure of another country in an effort to address problems within that country.

The transplants that have been successfully carried out in Indonesia can be seen in practice, (i) the transplantation of Islamic Family Law in the Indonesian legal system which has become an integration in the Islamic Law Compilation. (ii) the practice of establishing a Constitutional Court which was born from the various transplants of Austria, Germany, and South Korea. This can be carried out properly with due observance of basic things such as: first, comparisons that must be based on a strong understanding of the foreign legal system to be imitated, second, transplants are not carried out totally, but modified to suit the context of the legal, political system. and governments of host countries. What can be understood as a contextual legal transplant. ${ }^{10}$ In fact, the omnibus law has been used in Indonesia as can be seen in Government Regulation to Replace Law Number 1 of 2017 concerning Access to Financial Information for Taxation Purposes jo. Law Number 9 of 2014, Law Number 23 of 2014 concerning Regional Government and TAP MPR RI Number I / MPR/ 2003 concerning Review of the Material and Legal Status of MPRS Stipulations and MPR Decrees from 1960 to 2002.

So, the concept of omnibus law will be very compatible to be applied in Indonesia, where in fact there is no connection between the legal system and the government system in the context of implementing the omnibus law in a country, this can be seen in the examples

9 Vincent Suriadinata, Op. Cit., p. 125.

10 Mirza Satria Buana. (2017). Menakar Konsep Omnibus Law dan Consolidation Law untuk Harmonisasi Peraturan Perundang-undangan Hukum Tata Negara. Jurnal MPR RI. p. 355. 
of the Philippines, the United States, and Turkey. Then, the omnibus law transplant still pays attention to the domestic conditions summarized in the concept of political law and various considerations of the legal system in Indonesia, which basically is in accordance with Indonesian legal politics and constitutional to the 1945 Constitution. Because in fact, this form of omnibus law is not there is a connection with the government system and the legal system adopted in the destination country. ${ }^{11}$

Indeed, in the omnibus law discourse which is still very new and warm in Indonesia, there are many anti-thesis views with different argument backgrounds, such as: first, the omnibus law is a pragmatic legal mechanism by replacing norms with different political initiatives, where the bill is issued by the executive (President) so that the parliament is considered insensitive to the complexities and aspirations of the factions. So it is said that the omnibus law is considered undemocratic. Second, it is considered unsystematic because it contains many subjects.

However, behind the many existing regulations in Indonesia, the phenomenon of decreasing productivity appears as a paradox. Jimly Asshiddiqie said that these factors are plural and complex, first, the shift in the legislative function from the President to the Peoples Representative Council so that it is constrained in terms of data and information collection, expert staff, supporting funds, and deepening of official policies of state administration, second, the institutional bureaucracy of legislation increases which results in increased resources. drained and inversely proportional to regulatory productivity. third, the increased volume of People's Representative Council activities, and fourth, the law formation system that is oriented to the civil law tradition, even though the common law tends to show good legislative productivity. ${ }^{12}$

To overcome this trend, Jimly explained that there are at least two solutions, namely (i) the legislative mechanism which must be simplified and (ii) integrating the agenda for the formation of legislation with the practice of the omnibus law. Although omnibus is a common law practice, compatibility for use in civil law Indonesia can be applied. There are 3 circumstances for practicing the omnibus law, namely the amended law is directly related, the amended law is not directly related and the amended law is not related but 
in practice intersects. ${ }^{13}$

In the context of Legislation, the existence of the omnibus law wouldn't disturb the hierarchy of statutory regulations as in Article 7 of Law Number 12 of 2011. Because in fact, the omnibus law is a law with techniques that use techniques in legal products that have existed. As an umbrella law that is not recognized in the hierarchy of laws and regulations in Indonesia. So there is no need for a juridical basis for a law that clearly regulates this concept. Apart from that, the omnibus law a sich is not a way that is merely a "fast law", but only a deregulation approach to the formation of legislation to overcome hyper-regulation and over-regulation. If viewed more fundamentally, the omnibus law is an ordinary law whose regulations already exist in the Indonesian legal system. So that the process of planning, composing, discussing, ratifying, or stipulating and promulgating them is the same as in the formation of laws in general, with due observance of the principles of the formation of laws and regulations, types of hierarchy, and material content of statutory regulations.

Etymologically, omnibus law comes from Latin which means "for everything". The Black Law Dictionary, which is often used as a reference for definitions of Western legal terms, describes the omnibus law as an attempt to row once and over two or three islands. That is, one new regulation was deliberately formed at once to replace more than one other regulation that was already in effect.

Regarding the name omnibus law, from the term alone, it should be rejected because it violates the youth oath, especially when our president during a visit to Australia was proud to have used the Indonesian language coupled with regulations requiring the use of Indonesian. Omnibus law is clearly and definitely not Indonesian, let alone a regional language, even the term is still foreign to our ears. For that, replace it with Indonesian that is appropriate or the term from customary law as an alternative.

The ing of the Omnibus Law has caused a lot of debate among legal experts and there has even been resistance from workers' organizations. At least this illustrates that the Omnibus Law is not something that is easily agreed by all parties concerned.

Legal experts state that the preparation of the Omnibus Law requires a political cost that

13 Vincent Suriadinata, Op. Cit., p. 117. 
is not simple, considering that the Omnibus Law consists of very multi-sectoral and superpower issues. Moreover, Omnibus Law is a tradition in a country with an Anglo Saxon legal system so that it is not necessarily applicable in a country with a traditional Civil Law legal system such as Indonesia, coupled with a philosophical foundation that Pancasila should not be another ideology. The government plans to incorporate as many as 74 laws. Omnibus Law itself has the meaning of a statutory regulation that contains more than one regulatory content.

The term of the omnibus law is not found in Law No. 12 of 2011 concerning the Formation of Legislative Regulations as updated by Law No. 15 of 2019. However, the Omnibus Law is not something new in Indonesia. Because in shaping or changing a statutory regulation in Indonesia, it always refers to the principle of Lex superior derogat legi inferiori which aims like the omnibus law, namely harmonization between statutory regulations. Not only that, the government has made laws in the form of Omnibus Law and based on legal level theory, or ideally at the statute level or Government Regulation to Replace Law. Two forms of Omnibus Law have existed in Indonesia, namely: Government Regulation to Replace Law on Access to Financial Information for Taxation Purposes No.1 of 2017, and Law on Regional Government No. 23 of 2014.

Even though in its meaning the Omnibus Law will combine many multi-sectoral laws into one law, this does not mean that the Omnibus Law will later abolish all combined laws. This is because the Omnibus Law will only take certain articles related to the purpose of its formation to be incorporated into it.

The process of ing the omnibus law was procedurally flawed because it was carried out privately without the participation of civil society. The proof is that until now, civil society has not been able to access academic texts and the omnibus law. Public participation is important to gather input from various parties. There is no reason for the government not to open the bill because the has not been discussed with the DPR. This violates Article 89 jo 96 of Law No. 12 of 2011 concerning the Formation of Legislative Regulations which obliges the government to open access to all laws and regulations for the public even though academic texts are a must because from there we will see philosophical, sociological/empirical studies, which shows whether the omnibus law is needed by the community is not the opposite, especially if it is seen as an "order and haste" for whose 
interests it is also a juridical study.

Article 5 point g of Law 12 of 2011 concerning the Formation of Legislation, namely the principle of openness. Related to this principle, Article 170 of President Regulation Number 87/2014 concerning Implementing Regulations for Law 12 of 2011 requires the government and the DPR to disseminate the bill from the ing stage.

The Omnibus law design continues to surprise us. This time it is related to President Joko Widodo's authority to amend the Omnibus Law through a Government Regulation, it is naive and sad if that is true. Whereas according to the regulations, the right to change the law is the Peoples Representative Council-President or through a Government Regulation in Lieu of a Law instead of a government regulation. The above regulation is contained in Chapter XIII Other Provisions on the Omnibus Law as quoted by detik.com, Sunday (16/2/2020). Article 170 paragraph 1 states that the President has the authority to amend laws. "In the framework of accelerating the implementation of the strategic work copyright policy as referred to in Article 4 paragraph (1), based on this Law the Central Government has the authority to change the provisions in this Law and/or change provisions in the Law which are not amended in the Law. this, "reads Article 170 paragraph 1.

Article 4 of the employment Creation Bill regulates the Job Creation policy. Namely: (a). improving the investment ecosystem and business activities; (b). increased protection and welfare of workers; (c). convenience, empowerment, and protection of UMK-M and cooperatives; and d). increasing government investment and accelerating national strategic projects. "Amendments to the provisions referred to in paragraph (1) shall be regulated by a Government Regulation," reads article 170 paragraph 2. Surprisingly, a Government Regulation is the absolute authority of the executive. However, in the omnibus law, the ing of a PP is carried out in consultation with the DPR. "In the framework of stipulating the Government Regulation as referred to in paragraph (2), the Central Government may consult with the leadership of the People's Representative Council of the Republic of Indonesia," reads Article 170 paragraph 3.

In the hierarchy of laws and regulations which have also been regulated in Law Number 12 of 2011 concerning the Formation of Legislative Regulations (amended to Law Number 15 of 2019) Article 7. The hierarchy is the 1945 Constitution, MPR Tap, Laws, 
Government Regulations, Presidential Regulations, and Regional Regulations. So that every form of statutory regulation has its own content and process, and cannot conflict with those on it. The PP cannot contain any material on laws, let alone replace them, this is an "anomaly" of basic knowledge of Indonesian law.

This bill is also problematic in the hierarchy of laws and regulations and the decisions of the Constitutional Court. Article 170 in the employment Creation Omnibus Law Bill clearly violates statutory regulations. This is because government regulations should not be higher than laws. Obviously, it violates our statutory rules, where the position of the Law is above the PP, but through the Omnibus Law Article 170 PP is above the Law. Government regulations have a lower position than laws so they cannot cancel or change laws. Not only that, Article 166 of the Omnibus Law which states that a presidential regulation can cancel a regional regulation is also problematic. This provision is contrary to the constitution in accordance with the Decision of the Constitutional Court No. 56/PUU-XIV.

The ing of the Omnibus Law also violates at least two principles in ing legislation. One of them is the "principle of clarity" of the formula because the inclusion of the amendment article in the Omnibus Law is directly combined with the old article, making it difficult for anyone who reads it. The second principle that is violated is "can be implemented" because the implementing regulations for this Law must be made a month after being enacted as in Article 173 of the Omnibus Law.

Furthermore, Article 87 of the Omnibus Law of the Omnibus Law also regulates amendments to two articles of Law Number 40 of 1999 concerning the Press. The media workers considered this change to be carried out exclusively and did not involve stakeholders from the press. The Press Law is a product of reform in 1998. This law has never been amended. So it is really strange when the employment Creation Law involves changes in the Press Law. In addition, this change is called without the involvement of the community or press organizations. After all, journalists need to be involved in this change.

Thus it can be said that the issuance of this Omnibus Law has the tendency to violate the information rights of the Indonesian people which is actually one of the human rights. The rush of the omnibus law has also raised real suspicions about the interests and 
agenda of this design being a super-priority scale. Another oddity is that the academic manuscript that is a must is completely unknown, but in fact, a bill has been submitted to the Indonesia People's Representative Council.

Related to this aspect of the legal system, this is something new in our legal system which should require a strategic study, while from the priority scale of interest it is difficult to say that this is important and a priority to be made into an omnibus scale law product. So the honesty of the government and the DPR is demanded, what exactly is this agenda, please answer because the principles of governance are in addition to professionalism, accountability but also transparency and information is an important right of the people.

In achieving legal objectives, the omnibus law provides a conceptual significance that is inclusive of legal certainty and legal usefulness. Gustav Radbruch said that the law that has succeeded in guaranteeing a lot of legal certainty in society is a useful law where there are no contradictory provisions (must be based on a practical logical system), is made based on rechstwekelijkheid (a real legal situation) and there is no multiinterpretation term. This is in line with the concept of the omnibus law which basically provides legal certainty by deregulating regulations that are very complex, overlapping, and contradicting each other. Those in the status quo will negate the principle of legal certainty for the people.

The purpose of the law is seen in its function of protecting the interests of the people and of the law which has goals to be achieved. The teaching of law creates a correlation between the law and its people, which will create laws that are in accordance with the ideals of society. Therefore, the estuary of the purpose of the law is the benefit of the community itself. Therefore, the fat and overlapping and even opposing regulatory conditions will degrade the value of the legal usefulness itself. Where the community will experience difficulties in understanding the law and the purpose of the law as an advantage for the community will be left behind. Therefore, to ensure that law can provide benefits to the community, a simplification of regulations is needed through the concept of the omnibus law.

\section{Conclusion}

In the problem of hyper-regulation, overlapping and contradicting legal norms, the political configuration of the law forming the omnibus law bill shows that, first, official 
state policies in achieving state goals show that strengthening the economy and advancing the general welfare are the consequences of adopting the concept of a welfare state. Welfare state by Indonesia's rule of law and economic background are strong factors in encouraging the use of the omnibus law concept to achieve economic goals in Indonesia's 2045 vision.

Omnibus law is a legal concept originating from outside countries. In order to be applied in Indonesia, a legal transplantation method is needed in terms of legal comparisons by taking into account the context of the legal system and modification of the system according to the Indonesian legal system. Furthermore, the omnibus law will not interfere with the hierarchy of statutory regulations because in fact the omnibus law is applied the same as the system for forming ordinary legislation. Apart from that, the omnibus law will also provide significant legal objectives in the form of legal certainty and utility compared to the regular law revision method (one by one).

\section{Acknowledgement}

Many thanks to Faculty of Law of Universitas Muhammadiyah Sumatera Utara (UMSU) for always support me, so that I always productive in writing paper or doing research. Special thanks to Jambura Law Review for publishing this paper. 


\section{References}

Buana, Mirza Satria. (2017). Menakar Konsep Omnibus Law dan Consolidation Law untuk Harmonisasi Peraturan Perundang-undangan Hukum Tata Negara. Jurnal MPR RI.

Fitryantica, Agnes. (2019). Harmonisasi Peraturan Perundang-undangan Indonesia Melalui Konsep Omnibus Law. Jurnal Gema Keadilan. 6 (3).

Garner, Bryan A. Black Law Dictionary Ninth Edition.

HR, Ridwan. (2006). Hukum Administrasi Negara. Jakarta: RajaGrafindo Persada.

Indrati, Maria Farida. (2007). Ilmu Perundang-Undangan II. Jakarta: Kanisius.

Jimly Asshiddiqie. UU Omnibus: Penyederhanaan Legislasi dan Kodifikasi Administratif.

Krutz, Glen Stuart. (1999). Explaining Institutional Change: The Rise and Impact of Omnibus Legislating. Disertasi. Texas: Texas A\&M University.

Lbn. Toruan. Henry Donald. (2017). Pembentukan Regulasi Badan Usaha Dengan Model Omnibus Law. Jurnal Hukum. 3 (1).

Massicotte, Louis. (2013). Omnibus Law in Theory and Practice. Canadian Parliamentary Review.

Naskah Akademis RUU Cipta Kerja 2020.

Rahardjo, Satjipto. (1991). Ilmu Hukum. Jakarta: Citra Aditya Bakti.

Sagama, Suwardi. (2016). Analisis Konsep Keadilan. Kepastian dan Kemanfaatan Hukum dalam Pengelolaan Lingkungan. Jurnal Mazahib. 15 (1).

Sampara, Said., et. al. (2011). Pengantar Ilmu Hukum. Yogyakarta: Total Media.

Sueur, AP Le., JW Herberg. (1995). Constitutional and Administrative Law. London: Cavendish Publishing Limited.

Suriadinata, Vincent. (2019). Penyusunan Undang-Undang di Bidang Investasi: Kajian Pembentukan Omnibus Law di Indonesia. Jurnal Ilmu Hukum Refleksi Hukum. 4 (1).

Warrasih, Esmi. (1991). Implementasi Kebijaksanaan Pemerintah melalui Peraturan Perundang-undangan dalam Perspektif Sosiologis. Surabaya: Disertasi Pascasarjana Universitas Airlangga 